\title{
مرسوم الجمعيات العراقي ذو الرقم (19) لعام 1900 وموقف القوى الوطنية منه
}

\section{أ.م.د. علي فيري مطرود / كلية التربية/ جامعة واسط}

الباهث مر تضى صسن ناصر / مديرية تربية واسط

الاقدمة: الديمقر اطية، لذا اكتسبت الأحز اب السياسية مـ مرور الزمن أهمية خاصـة وقوة مؤثرة في التحكم بتوجيه وضبط قو اعد العملية السياسية، إضافة للدور الكبير التي تقوم به في تنشيط الحياة السياسية، و إدامة الصلة بين الحاكم و المحكومين، و اعداد القـادة والزعمـاء الذين يتحلون بقدرات القيادة و الخبرة في إدارة الثؤون العامـة للدولة.

ولتلك الأهميـة فـان نشـاط الأحز اب لابـد أن يخضـع لمجموعـة مـن الضـوابط التـي تفرضـها القو انين و التشريعات سواء من حيث آلية تشكيلها أو وسـائل عملها، وطبيعـة الأطر العامـة التي تتحرك داخلها وتنظم علاقتها سو اء فيما بينها وبين الدولة من جهة، وبينها وبين الأفر اد من جهة أخرى، لاسيما أن تلك العلاقة هي من تحدد في النهاية شكل وطبيعة النظام السياسي في البلاد. وكان للتطور ات السياسية التي شهدها العر اق في بدايـة خمسينات القرن العشرين، وتعاقب الحكومـات

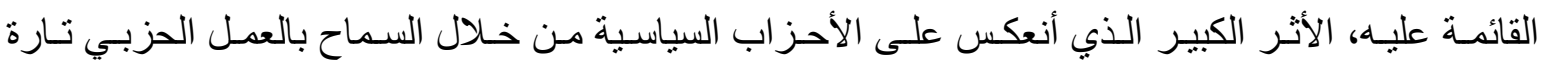
وتحريمه تارة أخرى فمثل هذا الو اقع خلق نوعاً من التذبذب في وجود الأحز اب وراحت الكثير منها تعمل في الخفاء وتظهر إلى العلن بعد أن يسـح لها بالعهل. وبمـا ان الأحز اب هي تجمعـات ذات صفة سياسية تم

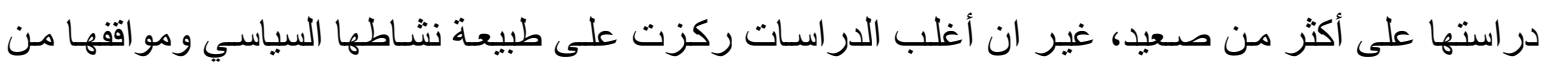
العمل الحكومي سلباً و إيجاباً، و أغفلت در اسـة القو انين و التشـريعات التـي نظمت عملهـا طيلة العهد الملكي

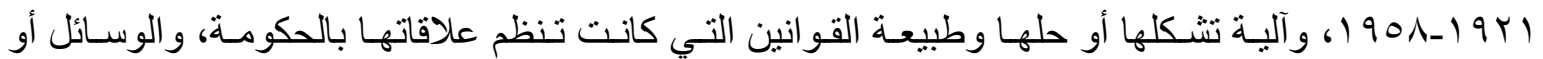
التفسيرات الدستورية والتشريعية التي كانت تعتمدها الحكومـة في أحيان كثيرة لتصفية حساباتها مـع تلك الأحزاب، لذلك سعينا لكتابـة بحث موجز عن أحد أهم القوانين الخاصـة بـالأحز اب و الجمعيات الصسادرة في البلاد خلال العهد الملكي وهو "مرسوم الجمعيات ذو الرقم (9 1 ) لعام ؛ ه9 ا".

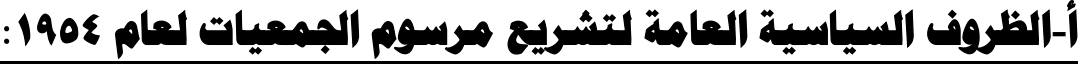

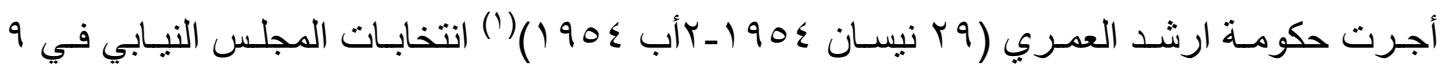

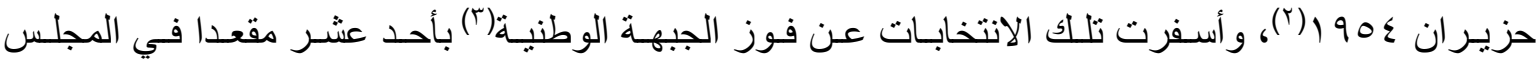
النيابي(؛)، وكاد العدد أن يزيد لو لا التدخل الحكومي في سير الانتخابات(ه). وعلى الرغم من عدد المقاعد القليل الذي فازت به الجبهة الوطنية نظير عدد مقاعد المجلس المتكونـة من مئـة وخمس وثناثون مقعدا، لكنـه احدث صـدى و اسـعاً لدى الفئة الحاكمـة في العراق و التـي اعتبرت ذلك الفوز بمثابـة تهديد لكيـان المملكة العر اقية، بسبب المبادئ و الأفكار التي آمنت بها اغلب قيادات الجبهة الوطنية(؟). 
أدى فوز الجبهة الوطنية إلى اتجاه الفئة الحاكمة في العراق ومن ور اءها السلطات البريطانية إلى تسليم مقاليد رئاسة الوزراء إلى نوري السعيد(`)، لان الجانب البريطاني كان راغباً بوجود شخصية قوية تستطيع أن تتفذ سياسة الأحلاف الاستعمارية التي تتبناها مع الولايات المتحدة الأمريكية، لغرض مواجهة النفوذ المتز ايد

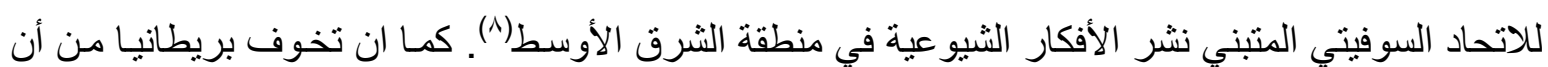

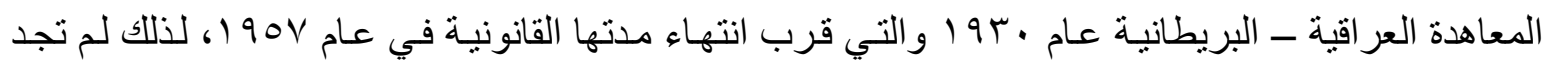

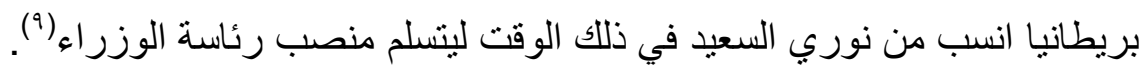

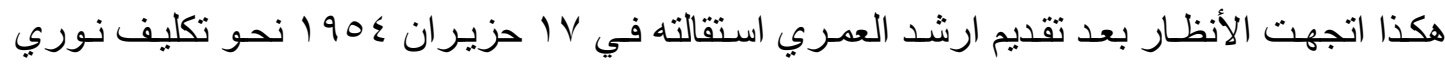

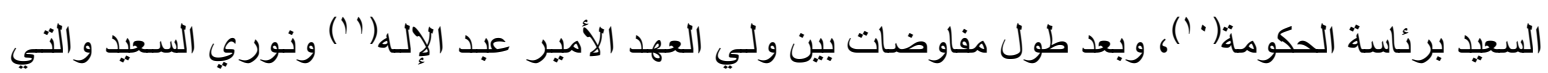

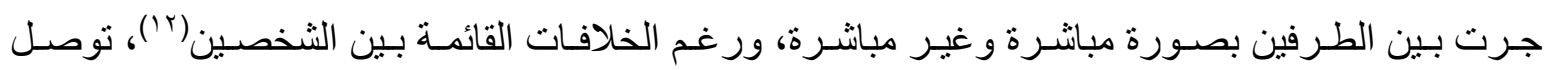

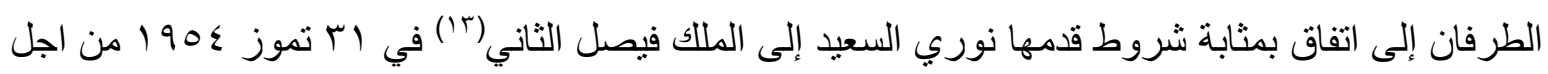

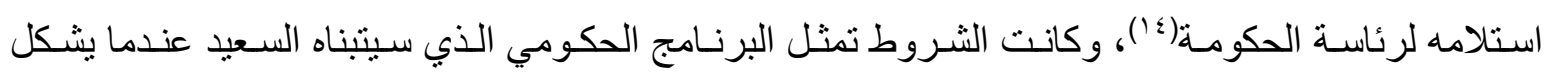
حكومته، وكان من ابرز شروطه في الجانب الداخلي هو حل مجلس النواب الذي لم يعقد سوى جلسـة واحدة لمان فقط(10)، وذلك من اجل استفتاء الثعب بجملة الإصلاحات التي سوف تقدم الحكومة على تنفيذهال(17). و افق الملك فيصل الثاني في ب آب ؛ 190 على شروط السعيد، وأعلن الملك الموافقة على استقالة العمري، وتكليف السعيد بتشكيل الوزارة الجديدة، وفي نفس اليوم أعلن الملك استتاداً إلى الفقرة الثانية من ونس

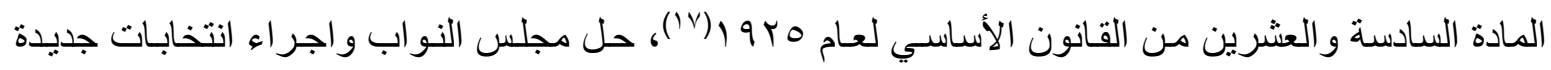
في الثاني عشر من أيلول ع 90 (') (').

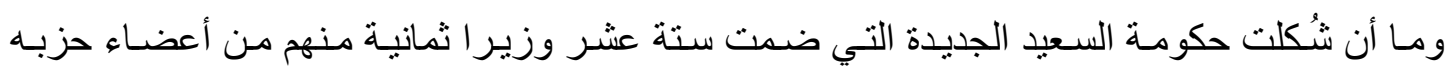
الاتحاد الدستوري و البقية من المستقلين المو الين لـه(9)، حتى عمدت إلى اتخـاذ سلسلة من الإجراءات التي وني هدفت من وراءها التحكم في الأحز اب والحياة السياسية في البلاد. فقد اتخذ السعيد في ب آب ع 190 آقراراً

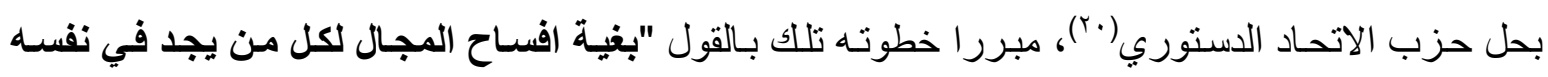
الكفاية لتمثيل الامة تمثيلا صحيحا دون ما تفريق او تحيز، فقد اتفقت مـع اعضساء حزب الاتحاد الاستوري

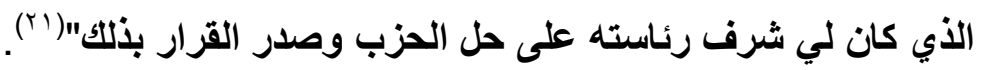
كماقام نوري السعيد بإصدار بيانات إلى الثعب العر اقي موضحا فيها السياسية العامـة التي ستنتهجها الحكومة مطالبا الثعب العر اقي بالابتعاد عن الأفكار و المبادئ الثيو عية الهدامـة قائلا "انتـانهيب بالعناصر الوطنية وهي تؤلف اكثرية الثعب العراقي النبيل ان تقف في وجه هذا الخطر الضـال الذي لا ولاء لـه لهذا البلا، والذي يستمد وحيه وتنظيمه من الاجنبي الطامع، وندعو المخلصين الى التعاون على دفع خطر هذا النفر،حفظالقوميتهم واعزازا للاينهم وحرصـا على سجاياهم الاصيلة ليظلـوا في معزل عن تأثير الهدامين وشـعار اتهم المضـللة"(r). و هكذا استخدم السعيد مخـاطر الثيوعية ومحاربتها غطاءا لمو اجهـة واضطهاد

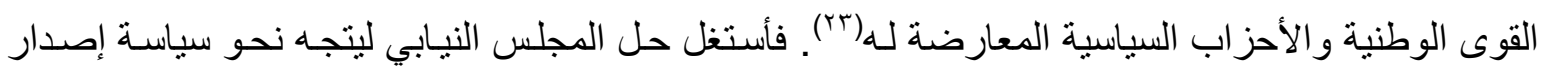




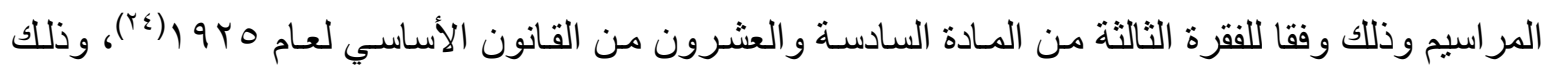

من اجل أحكام سيطرته على الأوضاع الداخلية والقضاء على جميع أصوات المعارضة أيا كان نوعهاب(ror.

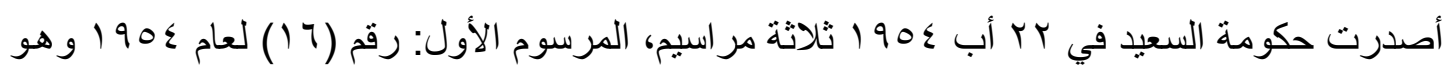

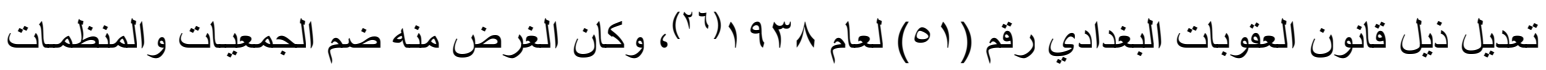
التي تروج أو تتعاطف مع المبادئ والأفكار الثيوعية للخضوع لنفس العقوبـات التي تفرض على العناصر

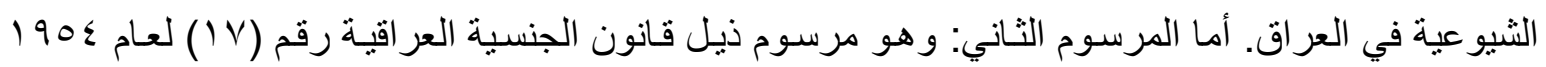

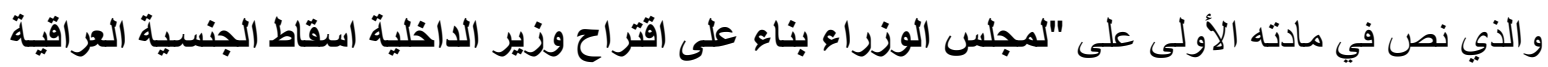

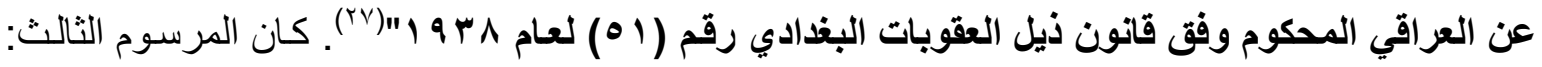

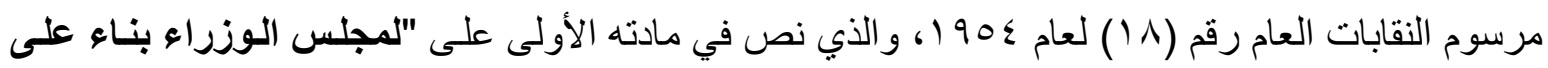
اقتراح وزير الداخلية ان يقرر غلق اية نقابة مؤسسة وفق قانونها الخـاص بصورة دائمـة او مؤقتة عندما تسلك النقابة مسلكا يمس الامن العام او يسبب اقلاق الراحة ممايدل على خروجها عن الاسس والمبادئ التي اسست من اجلها"(r^).

و اجه إصدار هذه المر اسيم معارضـه شديدة من قبل الأوسـاط الثعبية و السياسية، وهاجمتها الصحافة التابعة للأحز اب السياسية ، فنشرت جريدة "لواء الاستقلال" لسـان حال حزب الاستقلال مقالاً جـاء فيه "ان المراسيم لايمكن ان تحقق مكافحة الشيوعية، بل ربمـا لم تكن هذه الاغر اض هي اهدافها الرئيسية، وان القصد منها ارهاب المواطنين كي لا يقفوا ضد المشاريع المبيتة"(9)، فيما أكد الحزب نفسه أن هذه المر اسيم "جاوزت اقصى الدود في الثدة والقسوة والثذوذ وهي مغايرة كليا لمفاهيم الديمقراطية والعدالة"(·"). أما جريدة "صوت الأهالي" الناطق الرسمي باسم الحزب الوطني الديمقر اطي فانتقدت المر اسيم الثلاث قائلة "لعل اغرب مافي الامر وأبعد مافيه عن الاسس الايمقراطية الاستورية للحكم، ان تفكر الحكومـة الان في استصدار هذه المراسيم وعملية الاتتخاب تجري وتتم في وقت قريب ويتكون مجلس نيابي جديد بصرف

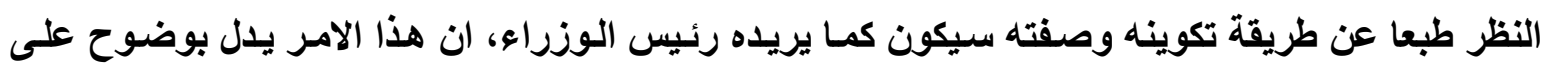

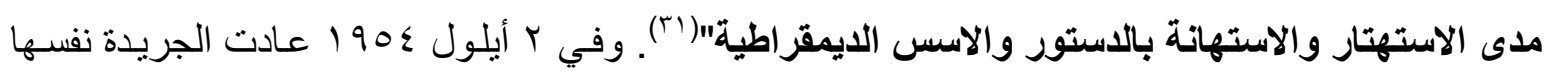

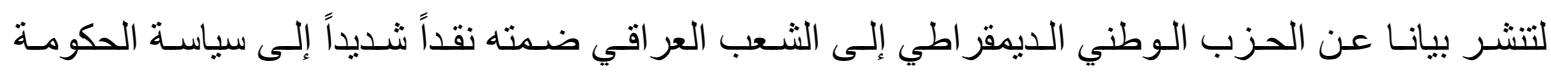

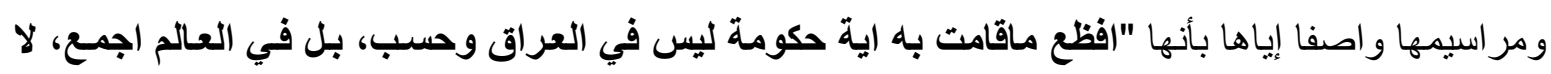
لانها تخالف المبادئ الديمقراطية وتخرق المبادئ الدستورية، بل لانها ضربت عرض الحائط احد الحقوق بهات الطبيعية المقدة للانسان وهو حق المواطنة"(r؟r).

ونتيجة لهذا الموقف المعارض من الحزب الوطني الديمقر اطي وصحافته، قررت وزارة الداخلية في

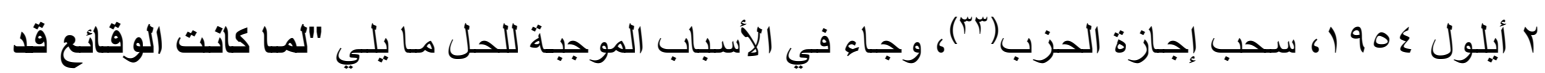
برهنت على ان تصرفات الحزب تهدف الى الاخلال بالامن واقلاق الراحة العامة وبالنظر لخروج الحزب عن

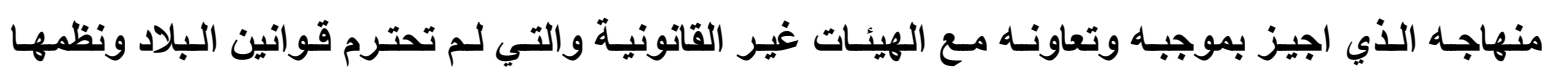
ولمخالفته القانونيـة المتكررة فقد قررت وزارة الداخلية سـب اجـازة الحزب وذلكت وفقا للمسادة العاشـرة 


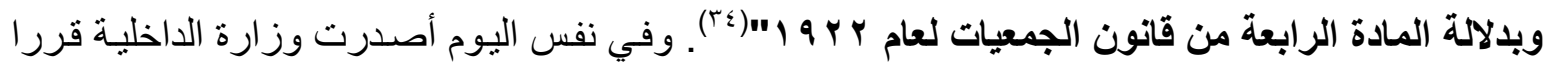
بتعطيل جريدة "الأهالي" عاماً كاملاًً (ro").

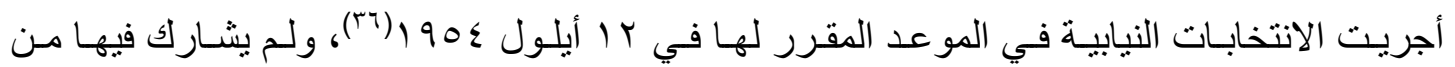
الأحزاب السياسية غير حزب الاستقلال فقط(rv). حيث أعلن الحزب الوطني الديمقر اطي المنحل عن مقاطعته

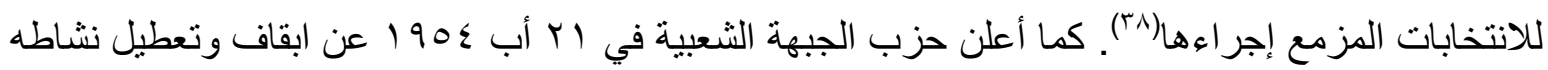

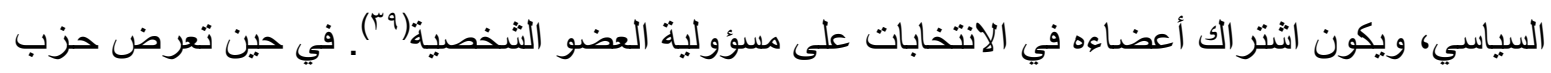

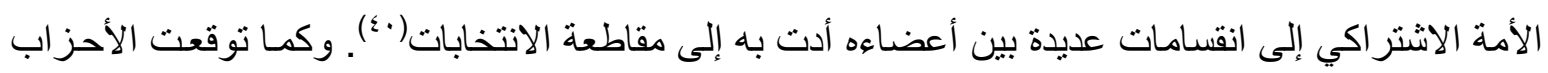

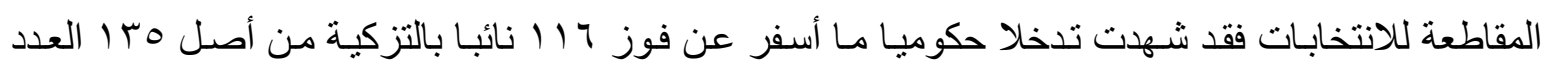

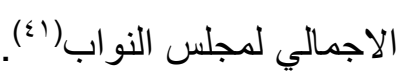
وبهذه النتائج ضمن نوري السعيد خلو المجلس النيابي من العناصر المعارضة لسياسته المزمع تنفيذها، وليضمن عدم وجود معارضـة سياسية لله خـارج المجلس النيابي عمل على أكمال مر اسبمه من اجل أحكام سيطرته على القوى الوطنية والأحز اب المعارضة، لذلك توجه نحو إصدار قانون جديد ينظم عمل الجمعيات

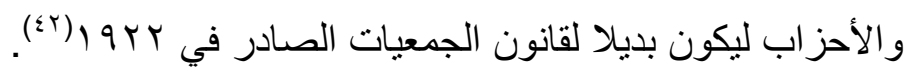
و افقت الحكومـة على لائحسة قـانون الجمعيـات التي وضـت مـن قبل حكومـة جميل المدفعي السـابقة

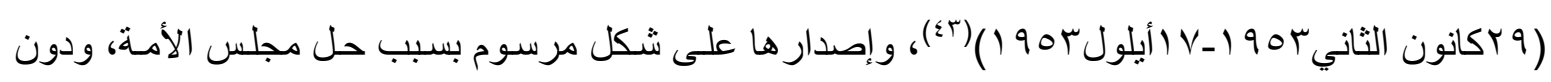

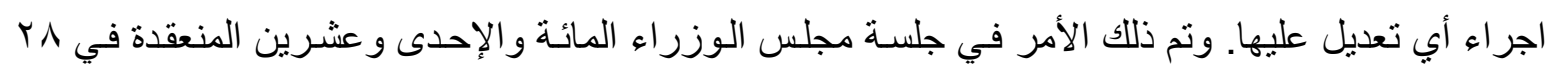

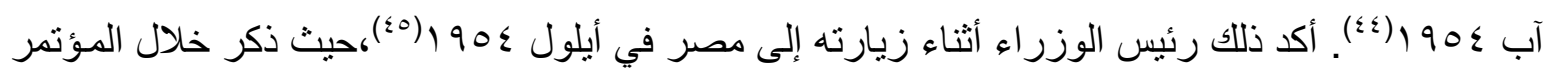
الصحفي الذي عقده هناك "بانه من الضروري ان يعاد النظر في تثكيل الاحزاب السياسية وفق احكام قانون جديد سينظم اعمال تأليف الجمعيات، وان مسودة هذا القانون كاتت قد أعدت من سنتين مضتا، وذلك لان الاحزاب والمنظمـات التـي تتثـابه في اهدافها وبرامجها يجب ان تتوحد في حزب واحد وعلى ذلك فـان القانون الجديد سيعالج هذه الناحية"(7؟).

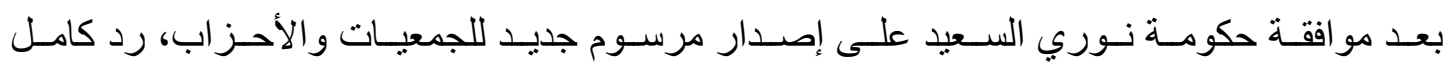

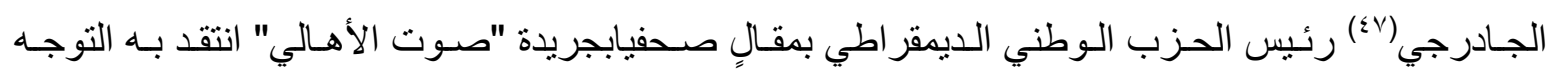
الحكومي قائلاً "بمناسبة مـاذكر من العودة مرة اخرى الى ذلك المشروع الذي يطعن الحيـاة الديمقراطية

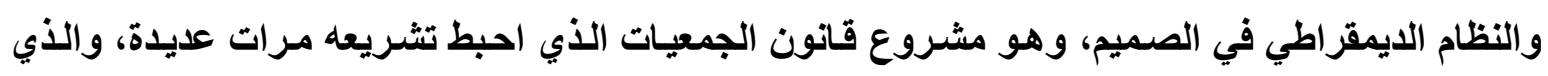
يريد رئيس الوزراء على ماذكر استصداره بمرسوم بالوقت الحاضر"، واضـافالجادرجي بـان الحكومـة تريد

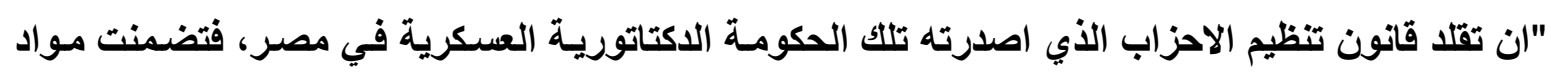

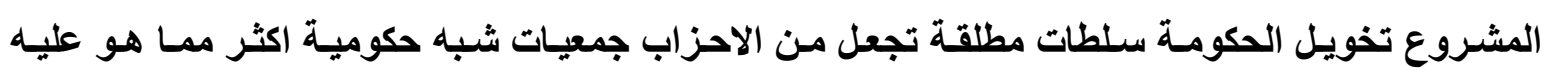
الوضع الان""(^). و هنا أثنار الجادرجي إلى ان حال الأحز اب في العراق تحت القانون الجديد سيكون كحال الأحز اب السياسية في مصر التي وضعت تحت طائلة الحل(9 ؛). 


\section{ب-هرسوم الجمعيات ذو الرقم (19) لعام 1900 :}

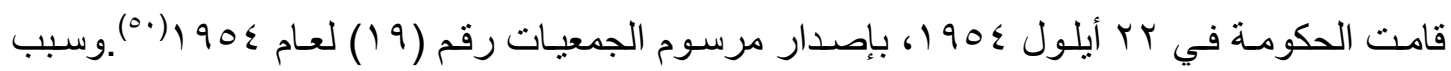
تأخر الحكومـة عن الإعـلان الرسـي لهذا المرسوم على الرغم الموافقة عليه في جلسـة مجلس الوزراء

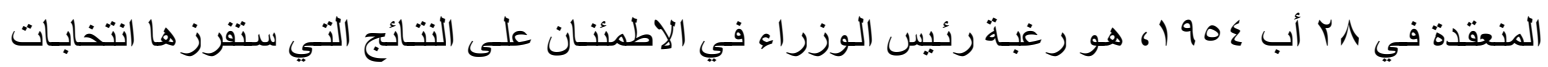
المجلس النيابي وخلوها من العناصر المعارضة له، وكذلك عدم رغبته في اثارة القوى السياسية المعارضـة

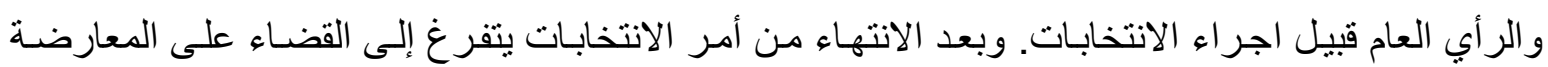
خارج المجلس النيابي، عن طريق الاستمر ار بسياسة المر اسيم وهذا ما تم بالفعل. ذكرت الحكومة أسباباً عديدة لأقدامها على إصدار هذا المرسوم في مقدمتها مـا وصفته بتجاوز بعضـها للقانون و المبادئ العامة للدولة و السـي لأثناره الفوضى لتحقيق مـآرب و أهداف خارجية وجـاء في بيـان ذلك السبب "ان بعض الجمعيات اخذت تجاهر بالدعوة الى مذاهب ومبادئ يعاقب عليها قانون العقوبـات كمـا ان

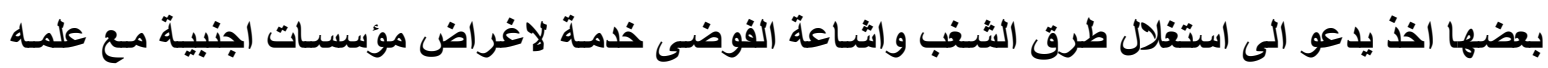
بان هذه الدعوة تتعارض ونظامه الذي اعلنه واجيز بمقتضـاه"، كمـا اضـافت الحكومـة سببا قانونيا وتنظيميا اخر هو تشابه الجمعيات والأحز اب مع أخرى أقدم منها في المبادئ والأهداف، وشعرت ان لأهدف عملي من ذلك، بل السعي فقط سوى السمعة والأهداف الخاصـة وذكرت "ان الواقع ان بعض الجمعيات يتفق نظامها الداخلي مع نظام جميعة قائمة قبلها مما يصبح تأسيس الجمعيـة المتأخرة في الوجود عبئـا لايقصد منـه الا

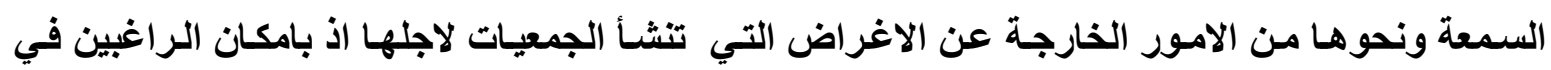

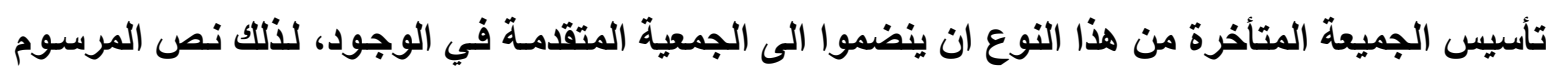

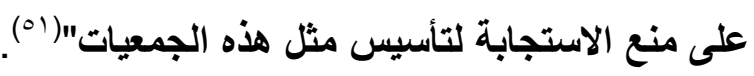
تألف مرسوم الجمعيات الجديد من واحد وثلاثين مادة، وزعت على خمسة أبواب :- الباب الأول: في التعاريف، الباب الثاني: في انشاء الجمعيات و إداراتها، الباب الثالث: في حل الجمعية، الباب الر ابع: في توحيد الجمعيات، الباب الخامس: في المخالفات و أحكام شتى. في فئ.

عرف المرسوم في الفقرة (أ) من المـادة الأولى الجمعيـة بأنها" هيئة ذات صفة دائمـة مؤلفة من عدة أثخاص طبيعية أو معنوية موحدين مطلوماتهم أو مساعيهم لتحقيق أغراض مشروعة غير الربح وتثـمل

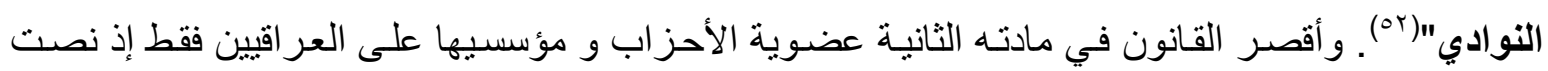

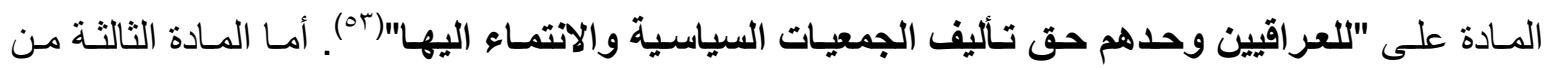
القانون فمنعت تأليف الجمعيات في بعض الحسالات ومنهـا أ. "لا يجوز تأسيس جمعيـة تهـف السى تحقيق غرض يخالف النظام العام او الاداب او يخل بـالامن العام او بوحدة البلاد او يرمسي الحى تغيير نظام الحكم

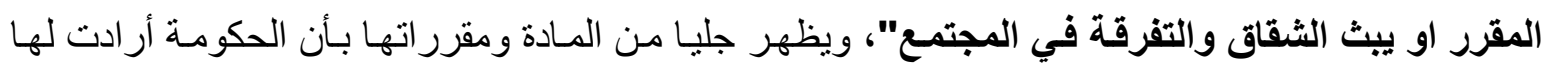

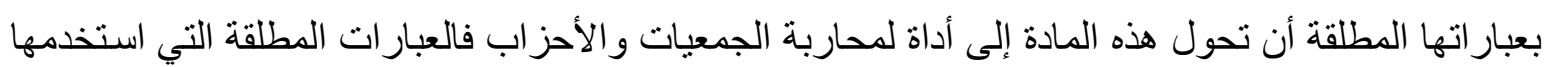

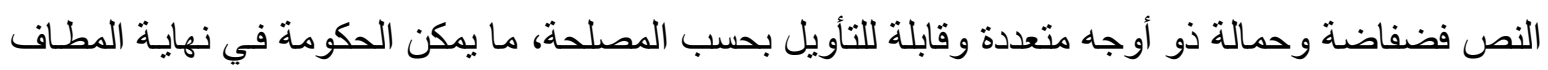
من استخدمها بهدف غلق أي جمعيـة أو حزب لا يتماثـى مـع مز اجها العام. بـ"لايجوز ان تؤسس جمعية 
سياسية على أسـاس العنصرية او المذهبية الدينيـة"، ج."لايجـوز تأسيس جمعيـة يتفق نظامهـا مـن حيث

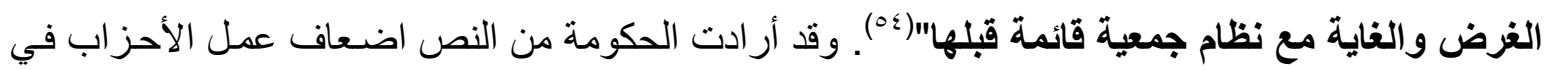
العر اق عبر التقليل من أعدادها بحجة تنـابه أهدافها، ويتضح ذلك من تركيز الحكومـة على أهداف الجمعيات و أغر اضها، وتناست وسائل و آليات تحقيق تلك الأهداف، إذ يمكن لهدف أن يكون مشترك لعدد من الأحزاب غير انها تختلف في آليات تنفيذه والوصول اليه. أكد مرسوم الجمعيات في مادتـه الرابعة على المتقدم لانشـاء جمعيـة أن يوضـع لها نظـام داخلي موقع

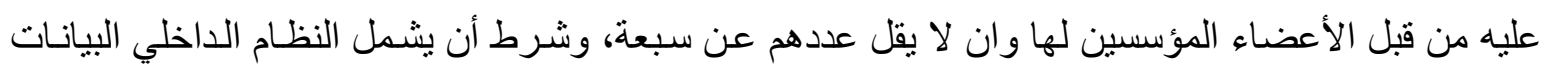

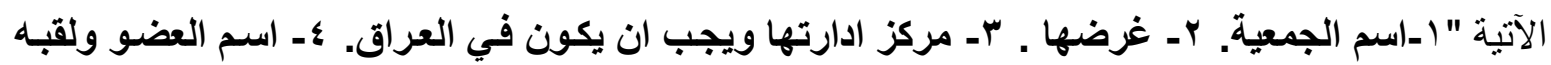

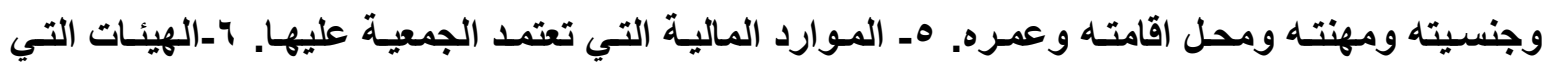
تتكون في الجمعية واختصاصات كل منها وطرق عزلهم. V- الطرق الواجبة الاتبـاع لتعديل نظام الجمعيـة.

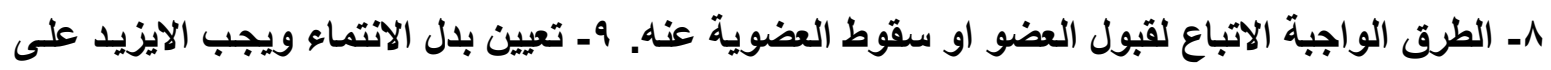

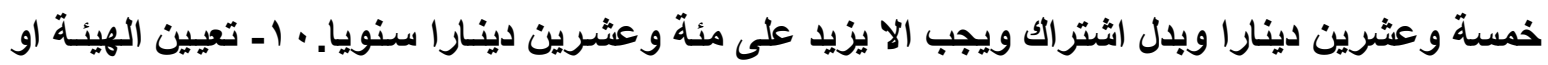
الشخص الذي يمثل الجمعية"(00).

في حين بين المرسوم في مادته الخامسة الأشخاص الذين لا يحق لهم الاتتمـاء إلى الجمعيات السياسية

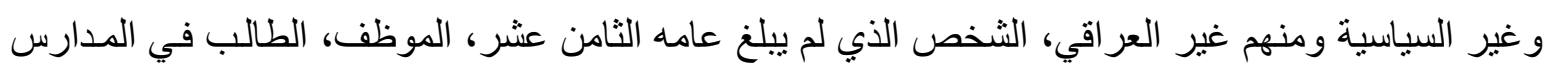

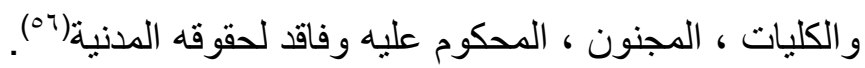

أعطى المرسوم في البـاب الثناني منـه الخـاص بإنشـاء الجمعيات و إدار اتها، صـلاحيات و اسعة لوزارة الداخلية للتنخل في شؤون الأحز اب والأشر اف عليها، أكثر مـا كان موجودا بقانون الجمعيات السـابق. فقد أكدت الفقرة (أ) من المادة السادسة من المرسوم على الر اغب بإنشاء جمعية أن يقدم طلب الإنشـاء إلى وزير

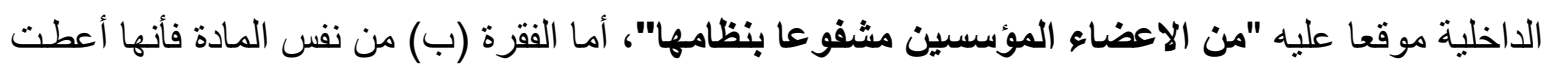
وزير الداخلية "مدة لاتزيد على ثلاثين يوما" من اجل الرد على طلب التأسيس، وأعطت الفقرة (ه) من المـادة

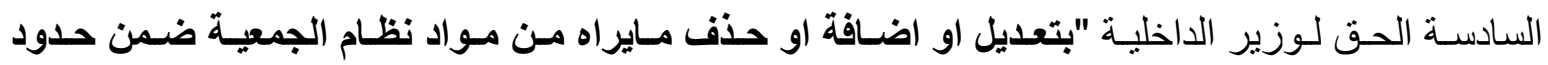
المرسوم"، في حين أعطى المرسوم في الفقرة (و) من المادة السادة الحق للأعضاء المؤسسين للجمعية التي

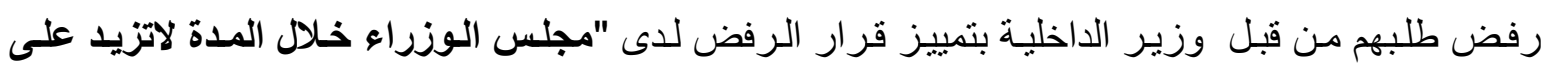
ثلاثين يوما"(or).

أجبر المرسوم في الفقرة (أ) من المادة الثامنة الجمعيات أن تبلغ وزير الداخلية "بكل تعديل تجريـه على نظامها ويكون هذا التعديل ناقذا اذا لم يقرر وزير الاخلية رفضه خلال خمسة عشر يومـا من صدوره"(ه).

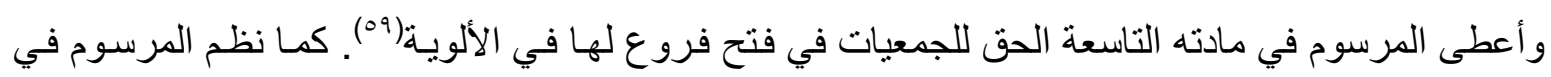

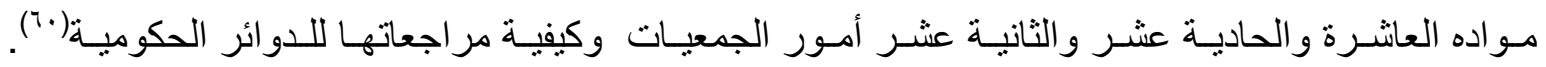

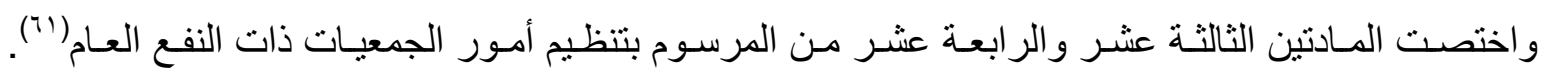

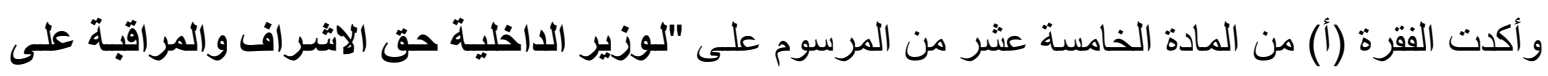


أمور الجمعيات ومعاملاتها كافة"، أما الفقرة(ب) من نفس المادة تؤكد على الجمعيات على ابداء التعاون مـع "المـوظفين الذي يعيـهم وزيـر الاخليـة لغرض المراقبـة والتفتيش مـن ممارسـة اعمـالهم وان تقدم لهـم

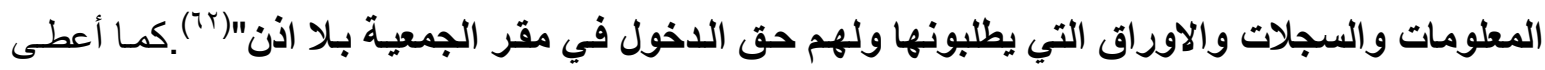
المرسوم في الفقرة (أ) من المادة السادة عشر الحرية لعضو الجمعية "في البقاء في الجمعية او الانسحاب منها وكل شرط في نظام الجمعية يخالف ذلك باطل"("T).

أجازت المادة السابعة عشر من المرسوم لوزير الداخلية أن يحل الجمعية في حدى الحـالات الآتيـة "أ-

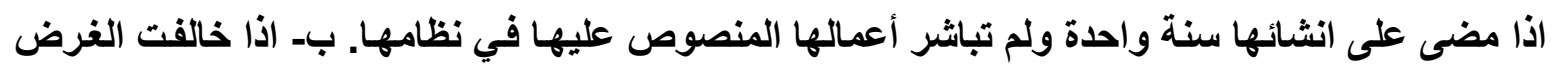
المؤسسة من اجله في اعمالها او في مقرراتها. ج- اذا قامت بعمل يؤدي الى الاخلال بـالامن العام او الاداب او قاومت تنفيذ احكام القوانين او استعملت الاكراه او العنف ضد الاخرين لحملهم على تأييدها واتت اي عمل من شأنه تحقيق اي من الاغراض المنصوص عليها في المادة الثالثة من هذا المرسوم. دـ اذا خزنت الاسلحة النارية او الجارحة او المواد المتفجرة او المفرقعة(عد ما كان منها للتسلية) في مركزها او مركز احد فروعها وتستثثى من ذلك الجمعيات والنوادي الرياضية"(๕)). وأعطى المرسوم في الفقرة (أ) من المسادة العشرين الحق للجمعيات المنحلة "بتمييز قرار وزير الداخلية بحلها لاى مجلس الوزراء خلال خمسـة عشر يوما من تاريخ الاعلان ويكون قرار مجلس الوزراء قطعيا"(70.). نصت الفقرة (أ) من المادة الثانية والعشرين على انـه "للجمعيات ذات الغرض الواحد او المتقارب ان

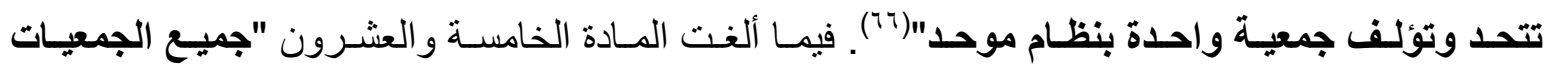

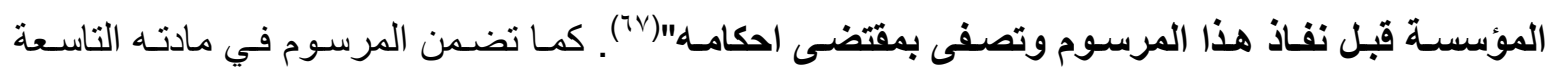

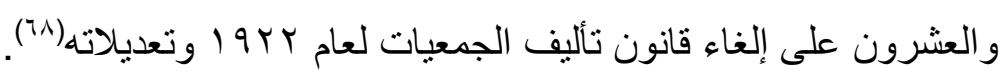
بعد إصدار الحكومة لمرسوم الجمعيات رقم (9 1 ) لعام 190 19 ، قامت وزارة الداخلية بإصدار بيان في

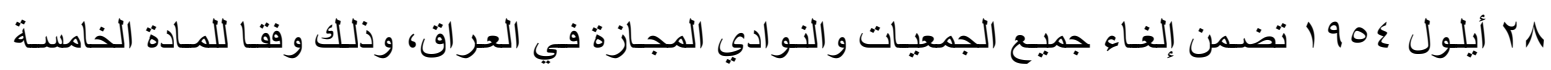

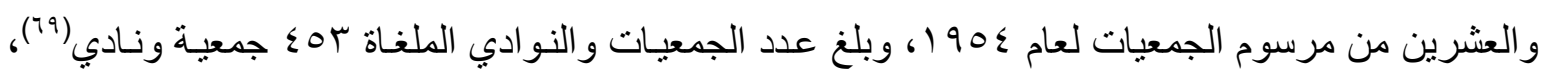
وتضمن البيان مطالبة القائمين على الجمعيات المنحلة بتقدم طلبات جديدة إلى وزارة الداخلية تكون مستوفية لكافة شروط المادة الرابعة من مرسوم الجمعيات لعام \9019 من اجل الحصول على أجازة جديدة( (V)، و لأجل

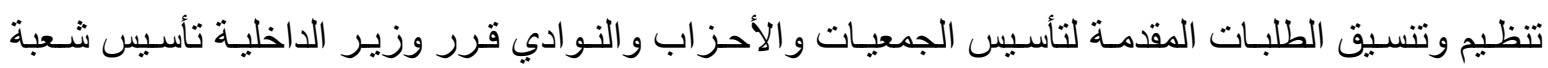
خاصة لهذا الأمر برئاسة كامل أمين ملاحظ الحدود (V).

\section{ت-هوقف القوى السياسية هن إصدار هرسوم الجمعيات ذو الرقم (19) لعام 1908 :}

و اجـه مرسوم الجمعيات لعـام 190 ا معارضـة شديدة من قبل الأوسـاط السياسية المعارضـة المتمثلة بحزبي الاستقلال والحزب الوطني الديمقر اطي، فقدم حزب الاستقلال مذكرة إلى رئيس الوزر اء ردا على قر ار حله، إضافة إلى شجبه لإصدار مرسوم الجمعيات الجديد(Yr). فأوضح الحزب في مذكرتـه "ان المرسوم الصادر بحجة تنظيم الاحزاب انما اريد به شل الحياة الحزبية بشكل كامل اكثر ممـا شهـه تاريخها الحديث، ورأت الى جانب ذلك ان هذه السياسـة الجديدة انمـا هي سياسـة تستمد اصولها من ايحاء الاجنبي، وهي 
تمهيد للتواصل الى اقرار الصلح مع اسرائيل، والتسليم بالمشاريع الاستعمارية المبيتة"(VT)، ووصف محمد

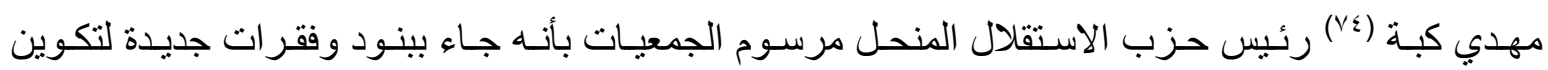
الأحزاب في العراق، وان إصدار المرسوم من أجل القضاء على المعارضة السياسية، ليتمكن رئيس الوزراء من تتفيذ مشاريعه الاستعمارية والتي تذهب بالعر اق إلى أحضان الدول الاستعمارية (voان.

انتقد كامل الجادرجي رئيس الحزب الوطني الديمقر اطي إصدار مرسوم الجمعيات، والذي عده نسخة للائحة قانون الجمعيات السـابقة الأعداد في عهد وزارة جميل المدفعي السـابقة، كمـا بين الجـادرجي مسـاوئ المرسوم وقال انه يحمل "العديد من الالفـاظ الغامضـة المطاطية مثل (تغير نظام الحكم المقرر) و (الاخلال بالامن العام) و (بث الثقاق والتفرقة في المجتمع)، التي يمكن استغلالها من قبل الحكومـة بكل سـهولة ضد الاحزاب المعارضة"(T^V)، كما وصف المرسوم بانه "مرسوم قد احتوى على اسس رجعية تستهدف الاحزاب

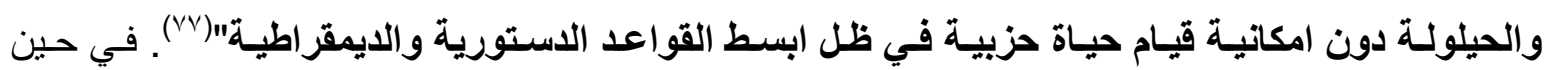
وصف محمد حديد(Y^)،احد الأعضاء البارزين في الحزب الوطني الديمقر اطي المرسوم بأنه "ازال التنظيمات السياسية من الوجود وقضى على التعدية التي هي شرط وجود النظام الاستوري"(V9). فيما حذرت باءهي السفارة البريطانية في العراق من خطورة سياسة المر اسيم المتبعة من قبل حكومة السعيد و التي أغلقت بموجبـه جميع الأحزاب السياسة، وذللك بتقرير هـا السنوي في 11 كانون الثاني عام 1900 و التي حذرت بـه حكومتها من "النتائج السيئة لسياسـة نـوري السـعيد ليس على النظـام الملكي في العراق فحسب وانمسا على مستقبل

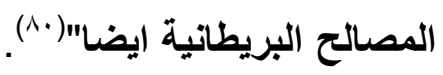

اختلفت آراء القانونين تجاه المرسوم فمنهم من عارضده، بحجة "انه مرسوم يخالف الاستور العراقي ، عملت الحكومـة على اصداره من اجل تثـديد القيود على الحركة الوطنية وشل البقيـة الباقيـة من الحيـاة

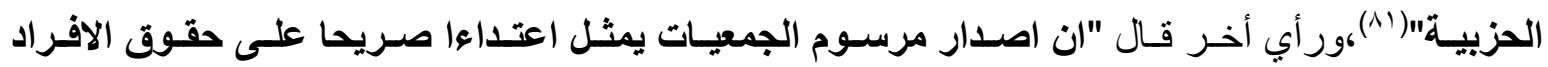

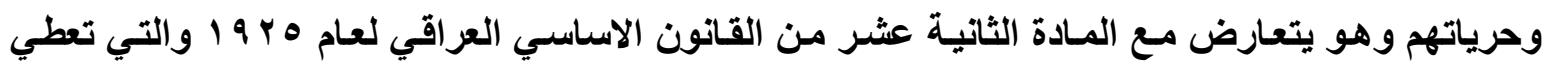
للعراقيين حرية الاجتماع وتأليف الجمعيات والانضمام اليها بحدود القانون"(^^). كما رحب البعض الأخر بالمرسوم وقال "بانه منظما وعلى قدر عال من دقة الصياغة القانونية لاتقاس على ماكـان عليه الوضع في

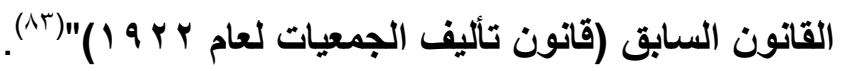

استمرت الحكومـة العر اقيـة بسياسـة إصـدار المر اسيم مـن اجل القضــاء على كل مظهر مـن مظـاهر المعارضـة السياسية في البلد. فأصدرت في • ا تثـرين الثاني ؟و 190 مرسوم المطبوعات رقم (؟Y) لعـام

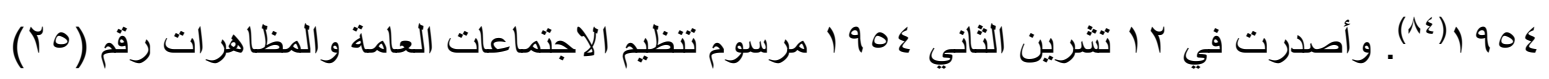

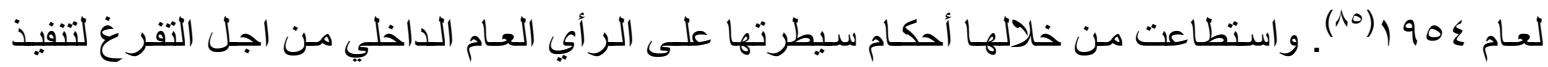
سياساتها الخارجية التي تهدف إلى التحالف و الدخول في أحلاف استعمارية خارجية تخدم في المقام الأول القوى الاستعمارية، ولكن رغم كل تللك الإجر اءات المتبعة من قبل الحكومـة في القضـاء على النشـاط الحزبي في العراق، كانت هناك محاو لات من بعض الثخصيات السياسية المعارضة من اجل استغلال صدور مرسوم

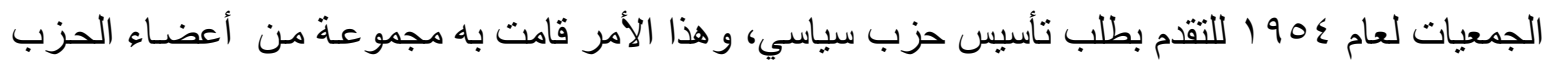


الوطني الديمقر اطي يتقدمه "كامـل الجـادرجي، ومحمد حديد، وحسبين جميل، وعواد علـي النجم، وعبد

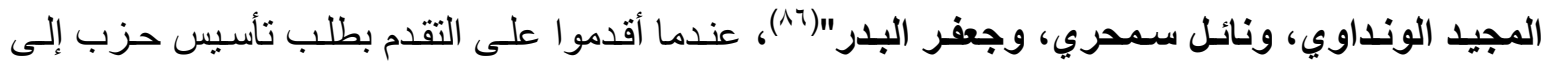

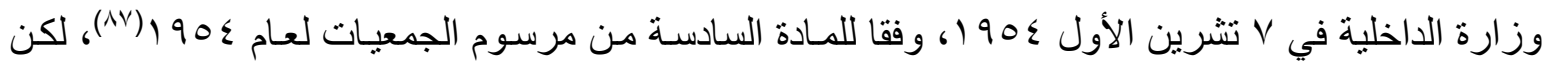
وزارة الداخلية رفضت الطلب في بr تشرين الأول بحجة "ان اسباب حل الحزب الوطني الديمقراطي مـاتزال قائمةة"(^^).

قام مقدمي طلب التأسيس بتقديم تمييزاً إلى مجلس الوزر اء ضد قرار وزير الداخلية(ه(^)، وذلك وفقا للفقرة (و) من المادة السادة لمرسوم الجمعيات والتي تنص على "للاعضساء المؤسسين تمييز قرار وزير الاخلية برد طلب الانشاء لدى مجلس الوزراء"(·9). لكن مجلس الوزراء أيد قرار وزير الداخلية ورفض تمييز مؤسسي الحزب الوطني الديمقراطي('). أسرعت الحكومة بعد ذلك لإصدار المزيد من القوانين التي تساعدها في التحكم أكثر في آليه تشكيل الأحزاب وصلاحية حلها ومن ذلك قانون الجمعيات ذو الرقم (rآ) لعام 1900.

|الغمانمة: من خلال العرض السابق لمرسوم الجمعيات ذو الرقم (9 (1) لعام ؟0 90 او الظروف المحيطه ياصداره، ر أينا من خلاله بطئ من الحكومة العر اقية وعدم اهتمام حقيقي في تطوير الحياة الحزبية في البلاد بما يتلاءم مع واقعها المتغير باستمر ار، فقد احتاجت الدولة لأكثر من اثنين وثلاثين عامـاً حتى تقوم الحكومـة بتعديل

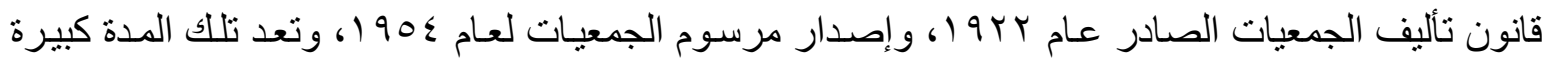
جداً بالنسبة لتشريع قانوني مرت على البلاد اثنائه العديد من المتغيرات السياسية الداخلية والخارجيـة. كمـا أوضحت الدر اسـة حرص الفئة الحاكمـة طو ال العهد الملكي و على الرغم من تشريعها للعديد من القو انين المنظمة لعمل الأحزاب و الجمعيات السياسية، سعيها الدؤوب لاستخدام شتى الطرق لمقاومـة تلك الأحزاب و واضعاف نشاطها، و عدم إفساح المجال لها، فوظفت في سبيل ذلك شتى أنواع سلطاتها القانونيـة والدستورية من مر اسيم وإعلان الأحكام العرفية وغير هما.

ومـن الأسباب التي سـاعدت على عدم تطور التشـريعات والقوانين الحزبيـة في العراق طوال العهد الملكي سيطرة فئة محددة من السياسيين على العملية السياسية، إضـافة إلى التدخل الحكومي في الاتنخابـات البرلمانيـة ممـا ولـد مجـالس نيابيـة ضـعيفة، أدت إلـى زيـادة سـطوة السـلطة التنفيذيـة على حسـاب السـلطة التشريعية، وبالتالي عدم التطور في أغلب القوانين والتشـريعات والتي اقتصر تشـريعها على السلطة التتفيذيـة المتمثلة بمجلس الوزر اءو غياب شبه تام للمجلس النيابية العر اقية المتعاقبة الذي اقتصر دور هـا على الموافقة على القو انين فقط.

لاحظنا كذلك هيمنة السلطة التنفيذية كانت الواضحة في مجال قبول ورفض طلبات التأسيس الخاصـة بـالأحزاب و القوى السياسية، ممـا أخل بالثـعار ات التي كانت ترفعها السلطات الحاكمـة آنذاك مـن استقلالية وحياد وموضو عية في التعامل مع هذا الملف، مما افقد الحياة السياسية في البلاد روح الديمقر اطية طيلة العهد الملكي، إضـافة إلى ان الفئة الحاكمـة ومن خـلال إصـدار ها للتشـريعات و القوانين لتنظيم العمل الحزبـي في 
البلاد، لم تكن ر راغبـة أساسـاً في تتـريعها لو لا نتيجة للظروف الداخلية المتمنلة بضغط من قبل الر أي العام و القوى السياسية أو لظروف خارجية، أو لرغبة بالتحكم في مصير تلك الأحز اب وزيادة سطونها على أركان الحياة السياسية في البلاد . و

على الرغم من الايجابيات والسلبيات التي عانت منها التشريعات والقو انين المنظمـة للعمل الحزبي في العر اق طيلة تاريخه المعاصر، الا أنها عدت نموذجاً للنظم الديمقر اطية التي كان العراق سباقاً بتشريعها في البلاد العربيـة، ومن خـلال مـا أفرزتـه مـن تعدديـة حزبيـة وتطور بـالفكر السياسـي العر اقي، حيث استطاع

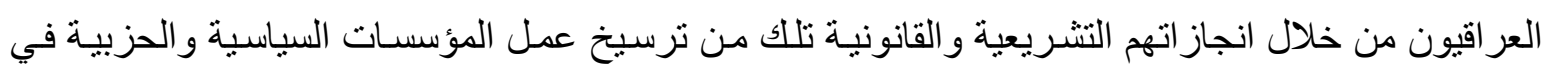
البلاد لوقت طويل.

\section{هوامش البمثث}

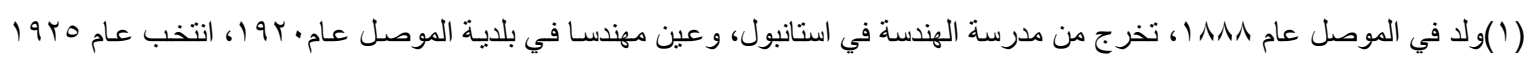

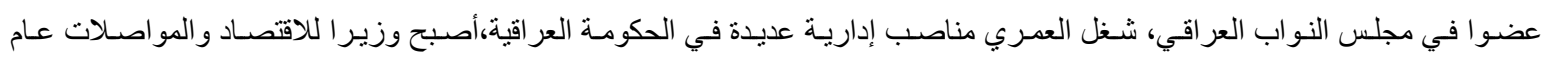

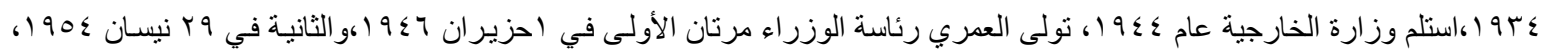

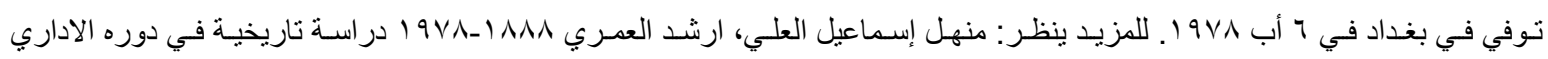

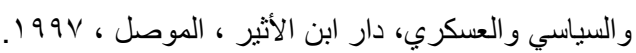

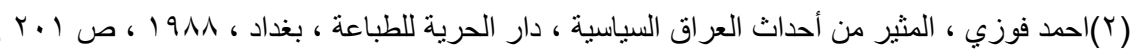

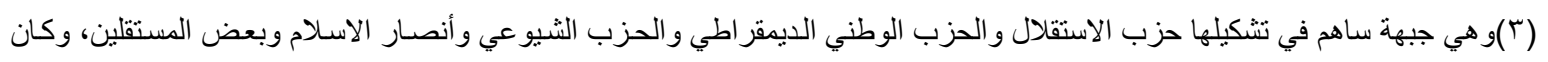

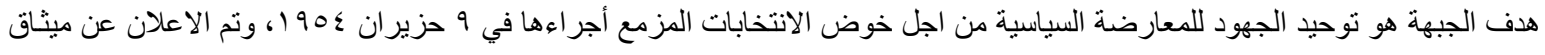

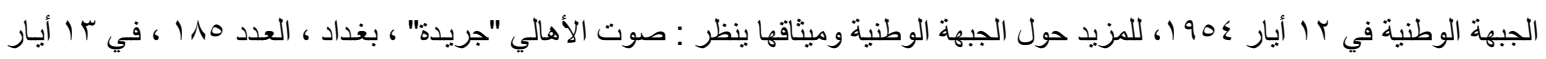

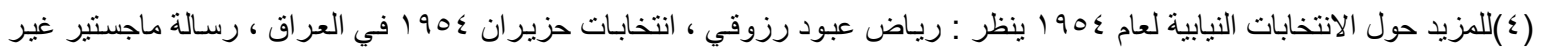

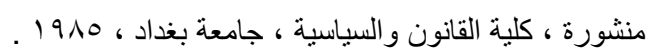

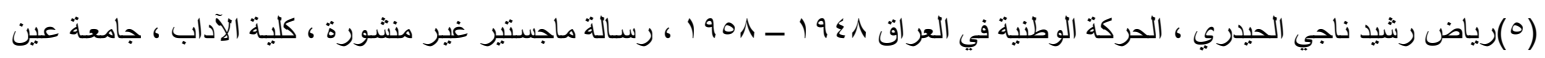

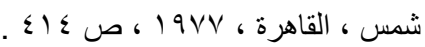

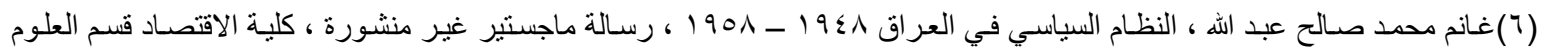

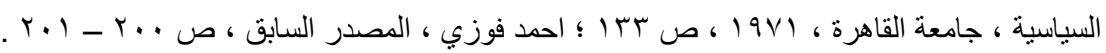

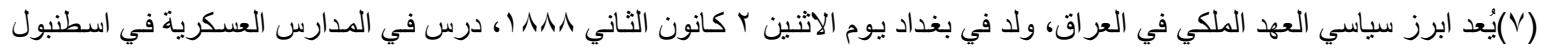

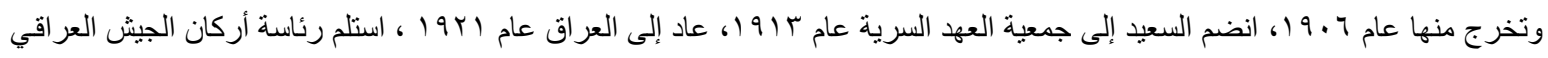

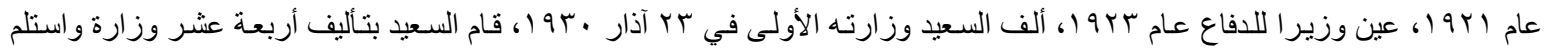

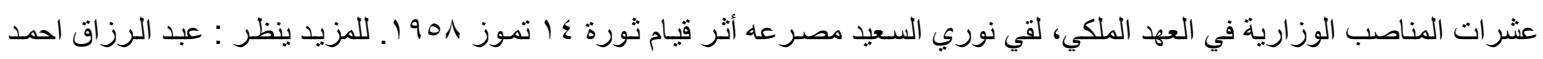

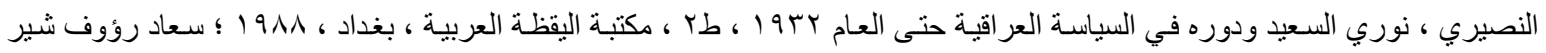

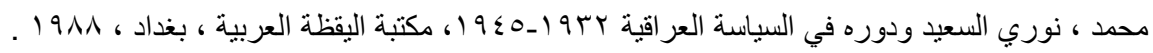

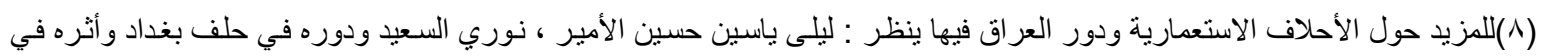

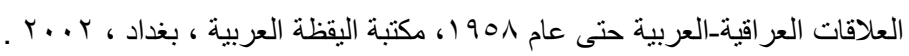

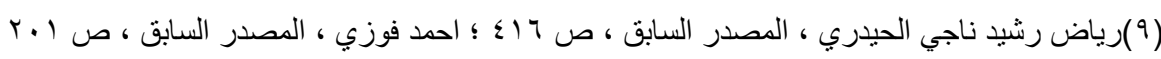

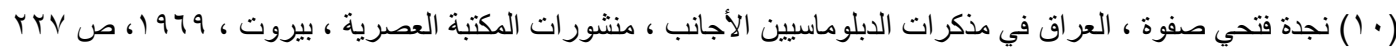

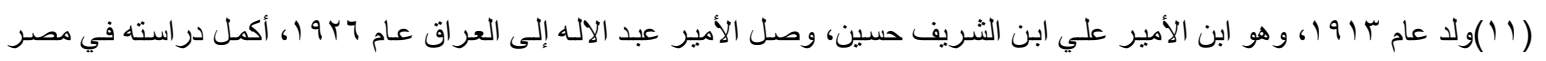

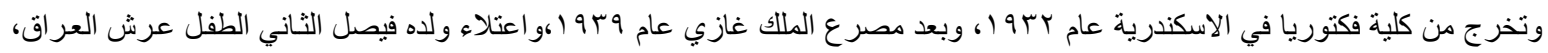

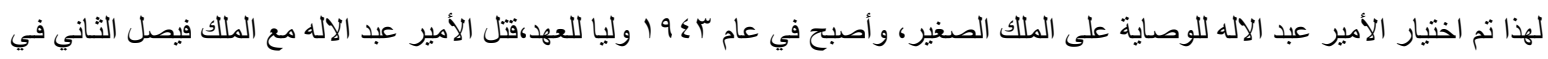




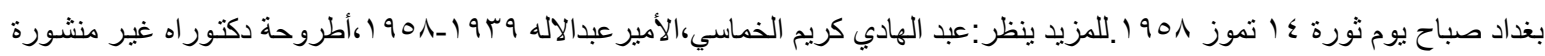

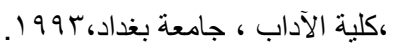

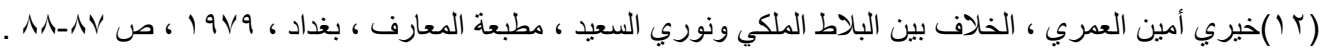

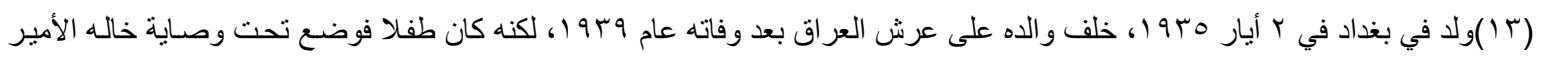

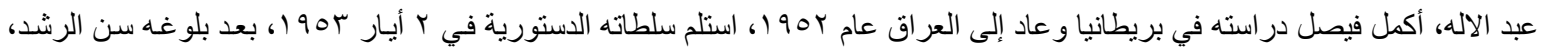

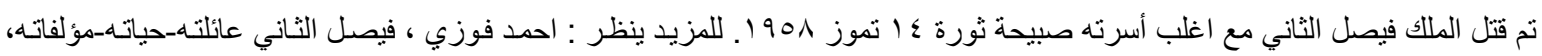

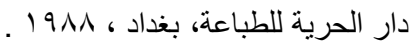

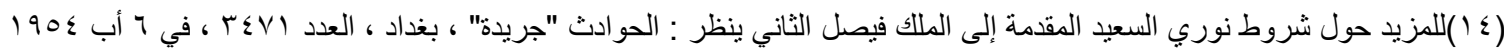

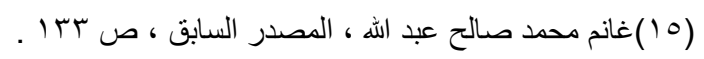

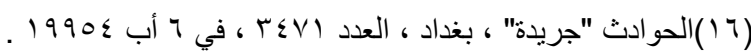
(IV) (IV) هذه الفقرة على أن "الملك يصدر الأوامر بأجر اء الانتخاب العام لمجلس النواب وباجتماع مجلس الأمة ويفتح هذا المجلس ويعطله ويفضه ويحل مجلس النواب وفقا لأحكام هذا القانون". للمزيد ينظر : رعد نـاجي الجدة ، التطورات الدستورية في العراق ، بيت الحكمة ،

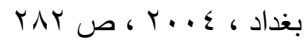

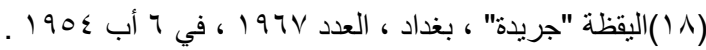

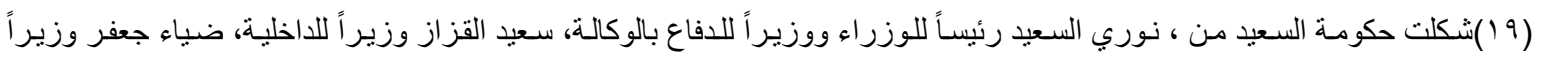

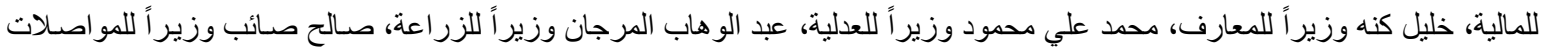

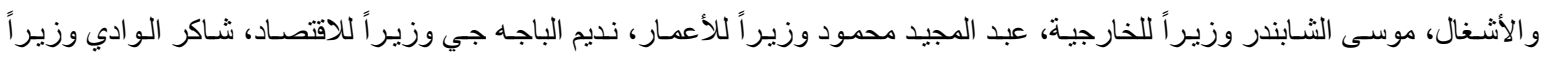

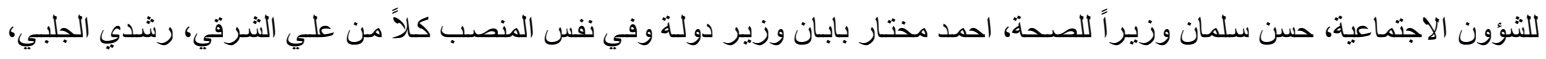

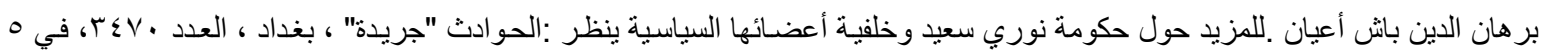

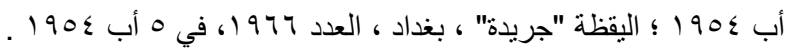

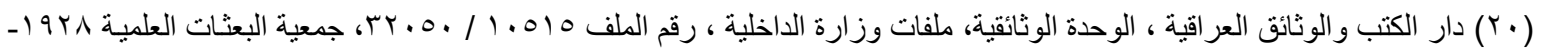

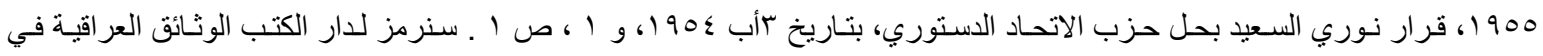

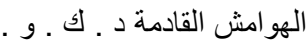

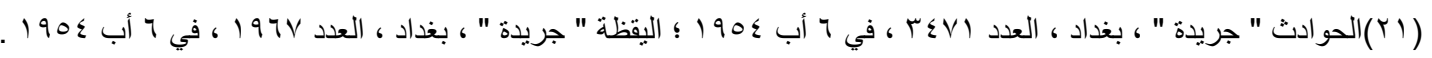

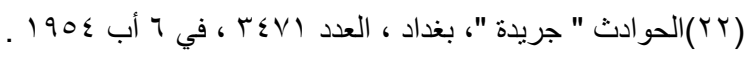

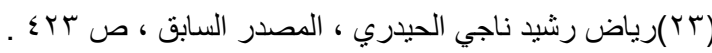

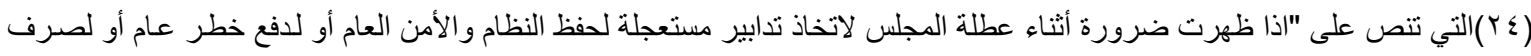

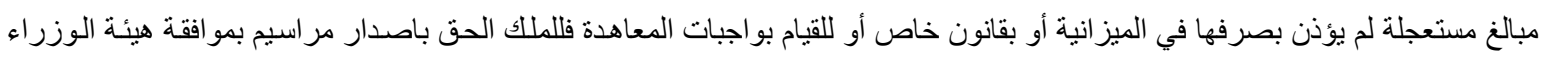

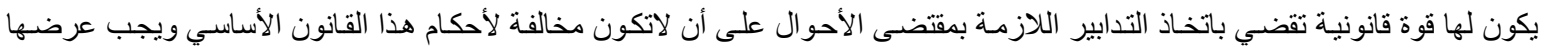

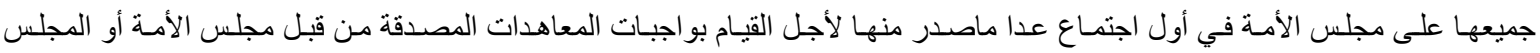
التأسيسي فان لم يصدق مجلسة الأمة هذه المر اسيم فعلى الحكومة أن تعلن انتهاء حكمها وتعتبر ملغاة من تاريخ هذا الاعلان ويجب أن تكون

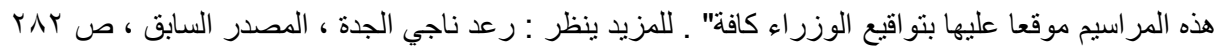

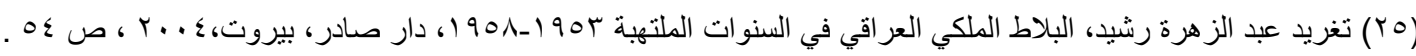

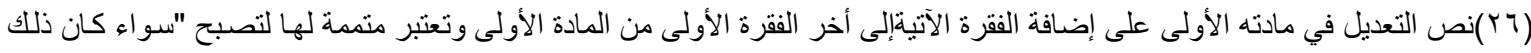

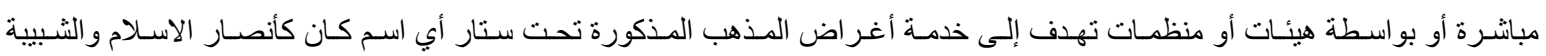

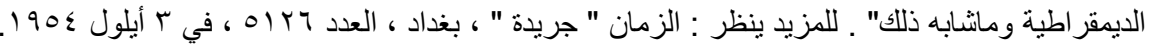

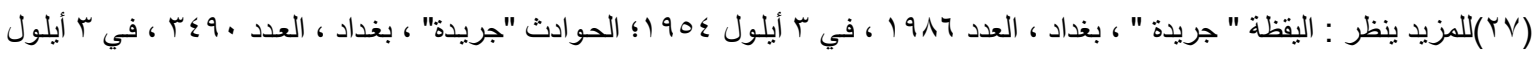
$.190 \leqslant$

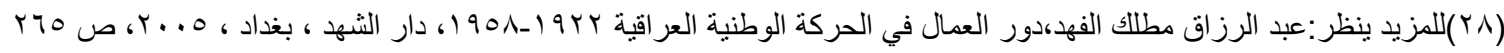

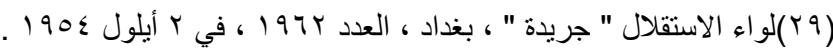

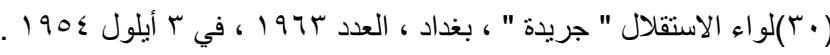




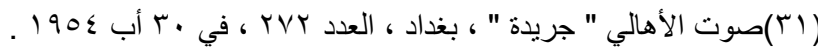

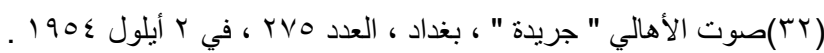

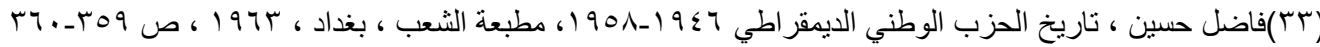

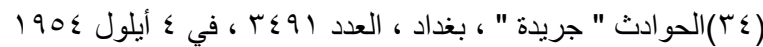

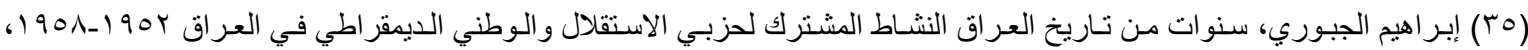

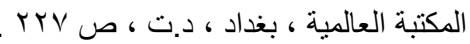

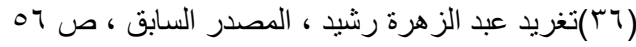

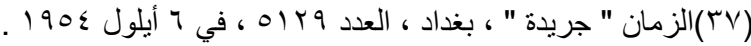

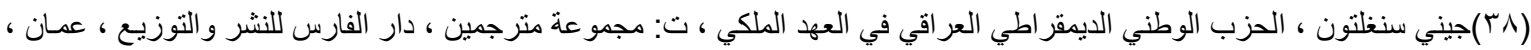

(

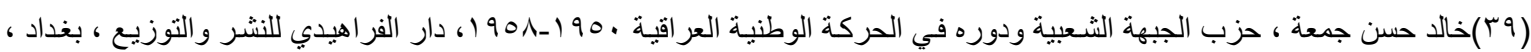

or ص r. r. Tr

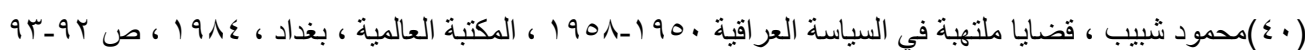

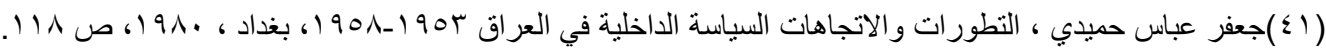

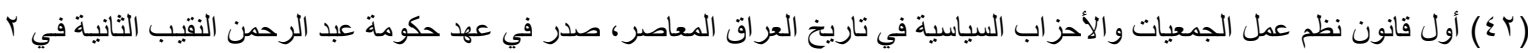

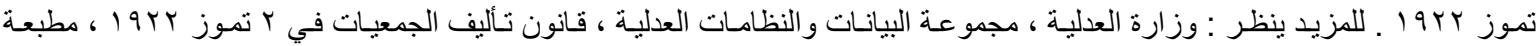

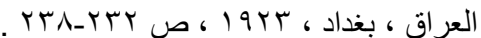

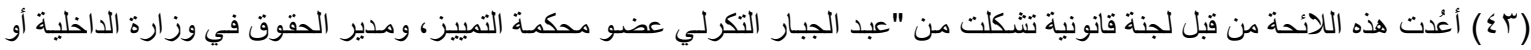
الثخص الذي يختارهوزير الداخلية، عبد الرحمن البزاز المدون القانوني في وزارة العدلية،شـاكر العاني المدعي العام في وزارة العدلية،

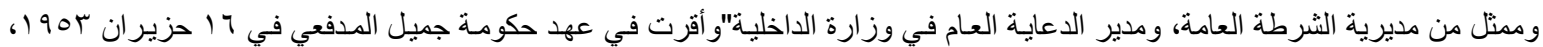
لكنها لم تشرع وذللك بسبب أن المجلس النيابي بعد رفع اللائحة لـه قد حل من قبل أن يشر عها فأهملت اللائحة بحكم المـادة (10) من النظام

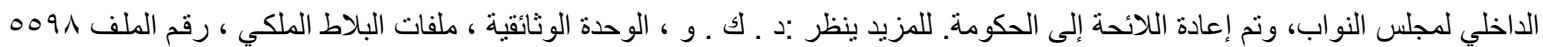

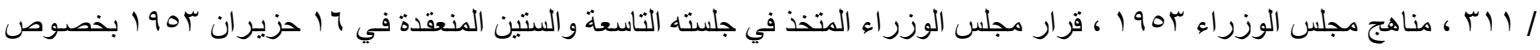

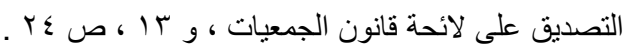

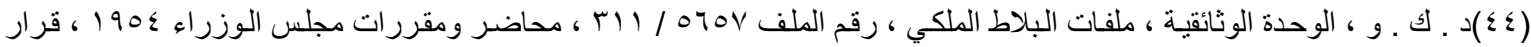

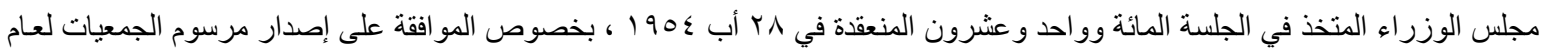
r

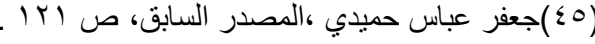

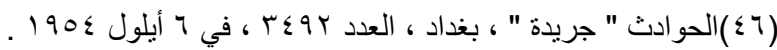

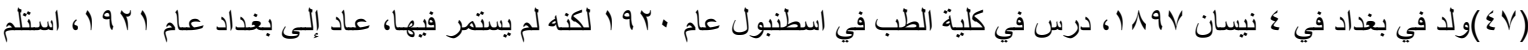

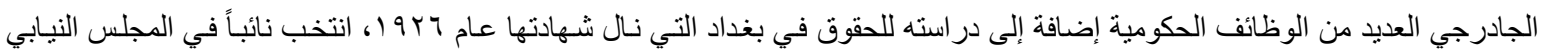

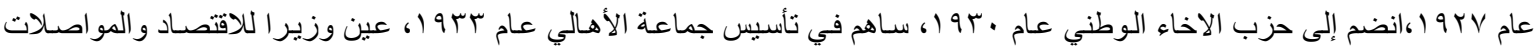

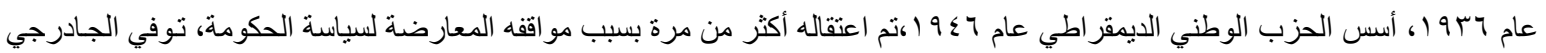

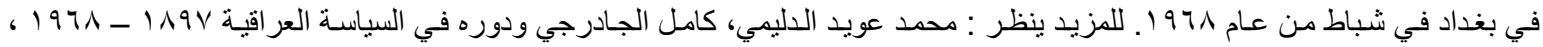

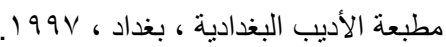

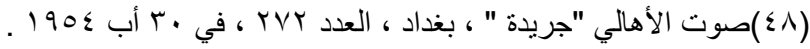

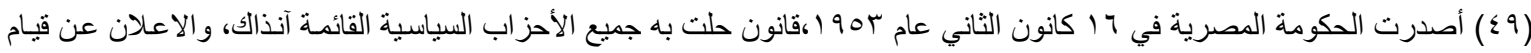
فترة انتقال لمدة ثلاث سنوات حتى تتمكن الحكومة من قيام حكم ديمقر اطي دستوري سليم ـ للمزيد ينظر: الوقائع المصرية "جريدة" ، القاهرة،

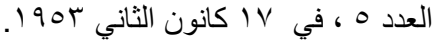

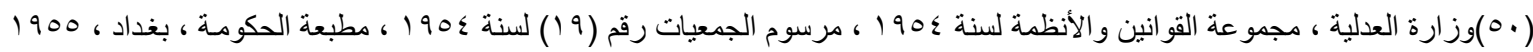

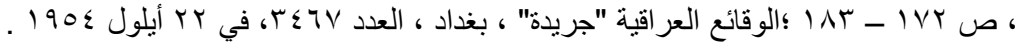




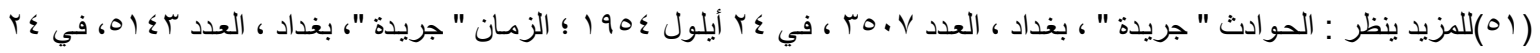

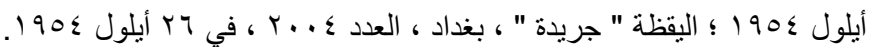

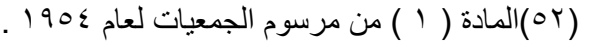

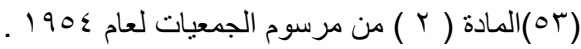

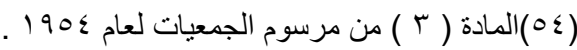

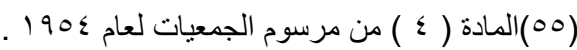

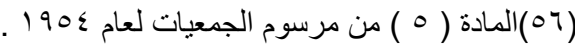

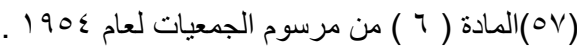

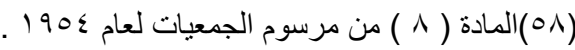

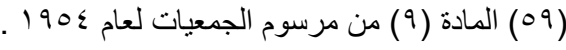

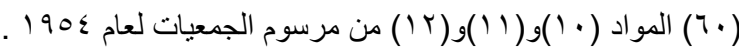

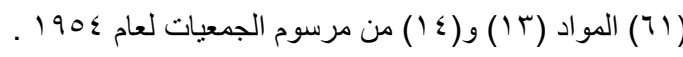

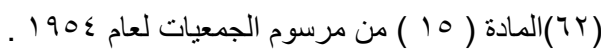

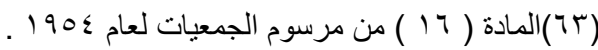

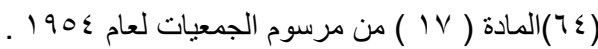

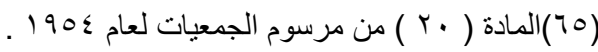

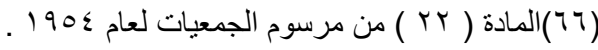

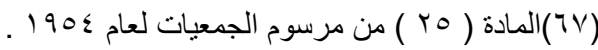

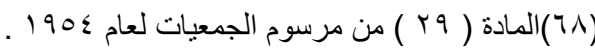

(79)وجدنا اختلاف في عدد الجمعيات و النو ادي المنحلة عند اغلب المصادر ، لكني اعتمدت على العدد الموجود في جريدة الوقائع العر اقية.

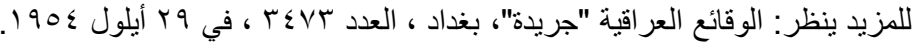

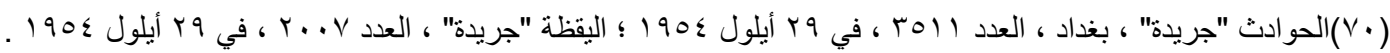

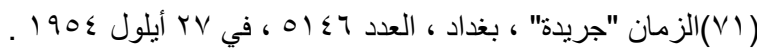
الزمان "جريدة" ، بغداد ، العدد (VY)

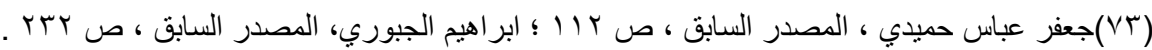

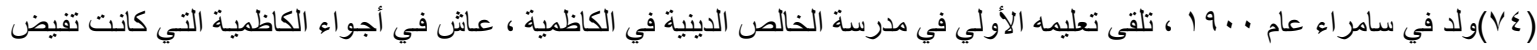
بالنشاط السياسي المعادي للبريطانيين ، ساهم في ثورة العشرين، ساهم عام هبو 1 بتأسبي نـادي المثنى بن حارثة الثيباني وتم انتخابه نائبا

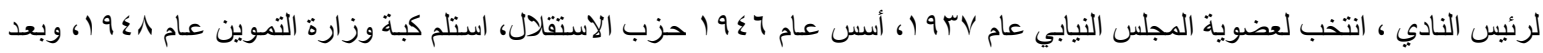

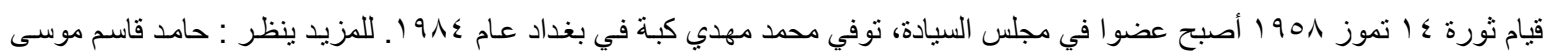

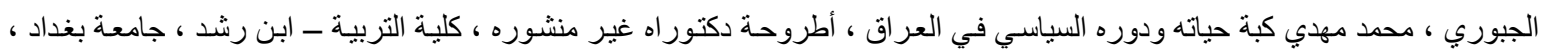

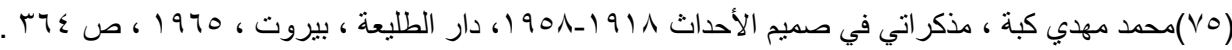

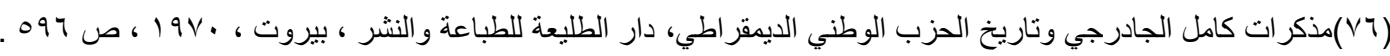

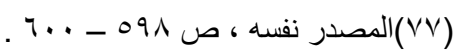

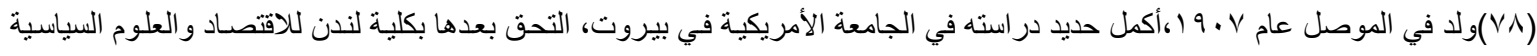
وتخرج منها عام اس و ا، وبعد عودته إلى العراق عين موظفا في وزارة المالية،كان حديد من مؤسسي جماعة الأهالي،انتخب نائبا في مجلس

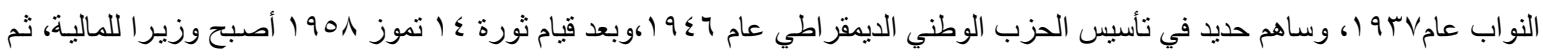

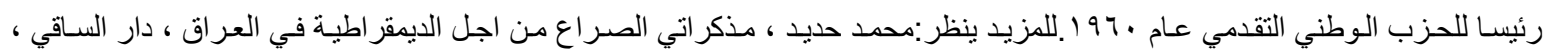




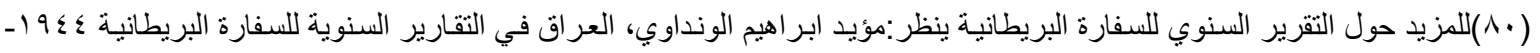

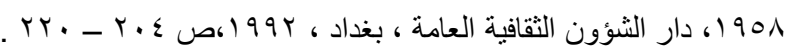

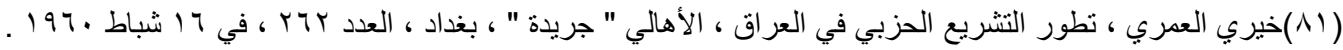

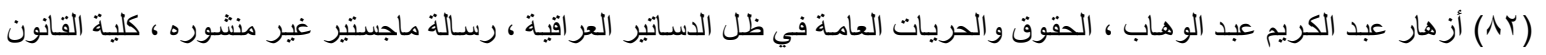

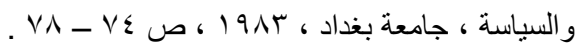

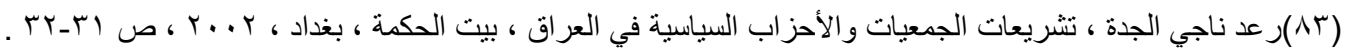

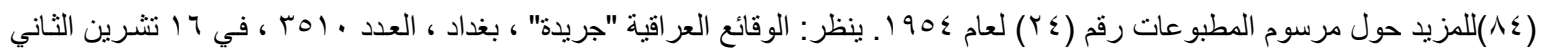
$.190 \leqslant$

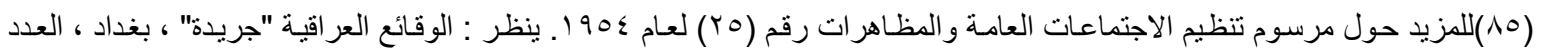

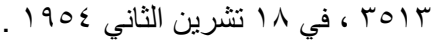

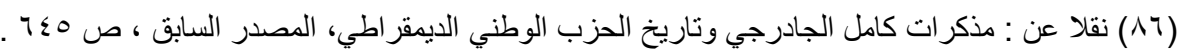

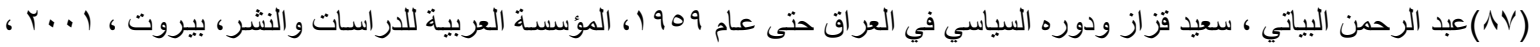
ص זrו

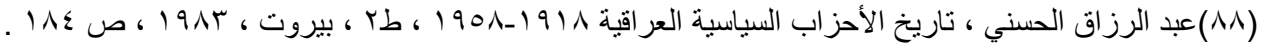

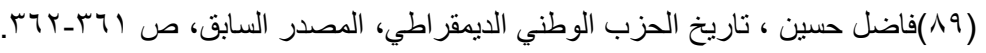

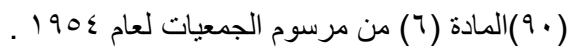

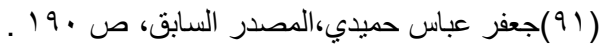

